University of Montana

ScholarWorks at University of Montana

$7-2008$

\title{
Is the Effect of Forest Structure on Bird Diversity Modified by Forest Productivity?
}

Jacob P. Verschuyl

Andrew J. Hansen

David B. McWethy

Rex Sallabanks

Richard L. Hutto

University of Montana - Missoula, hutto@mso.umt.edu

Follow this and additional works at: https://scholarworks.umt.edu/biosci_pubs

Part of the Biology Commons

Let us know how access to this document benefits you.

\section{Recommended Citation}

Verschuyl, Jacob P.; Hansen, Andrew J.; McWethy, David B.; Sallabanks, Rex; and Hutto, Richard L., "Is the Effect of Forest Structure on Bird Diversity Modified by Forest Productivity?" (2008). Biological Sciences Faculty Publications. 281.

https://scholarworks.umt.edu/biosci_pubs/281

This Article is brought to you for free and open access by the Biological Sciences at ScholarWorks at University of Montana. It has been accepted for inclusion in Biological Sciences Faculty Publications by an authorized administrator of ScholarWorks at University of Montana. For more information, please contact scholarworks@mso.umt.edu. 


\title{
IS THE EFFECT OF FOREST STRUCTURE ON BIRD DIVERSITY MODIFIED BY FOREST PRODUCTIVITY?
}

\author{
Jacob P. Verschuyl, ${ }^{1,4}$ Andrew J. Hansen, ${ }^{1}$ David B. McWethy, ${ }^{1}$ Rex Sallabanks, ${ }^{2}$ and Richard L. Hutto ${ }^{3}$ \\ ${ }^{1}$ Ecology Department, P.O. Box 173460, Montana State University, Bozeman, Montana 59717-3460 USA \\ ${ }^{2}$ Idaho Department of Fish and Game, 600 S. Walnut, P.O. Box 25, Boise, Idaho 83707 USA \\ ${ }^{3}$ Avian Science Center, Division of Biological Sciences, University of Montana, Missoula, Montana 59812 USA
}

\begin{abstract}
Currently, the most common strategy when managing forests for biodiversity at the landscape scale is to maintain structural complexity within stands and provide a variety of seral stages across landscapes. Advances in ecological theory reveal that biodiversity at continental scales is strongly influenced by available energy (i.e., climate factors relating to heat and light and primary productivity). This paper explores how available energy and forest structural complexity may interact to drive biodiversity at a regional scale.

We hypothesized that bird species richness exhibits a hump-shaped relationship with energy at the regional scale of the northwestern United States. As a result, we hypothesized that the relationship between energy and richness within a landscape is positive in energylimited landscapes and flat or decreasing in energy-rich landscapes. Additionally, we hypothesized that structural complexity explains less of the variation in species richness in energy-limited environments and more in energy-rich environments and that the slope of the relationship between structural complexity and richness is greatest in energy-rich environ-
\end{abstract} ments.

We sampled bird communities and vegetation across seral stages and biophysical settings at each of five landscapes arrayed across a productivity gradient from the Pacific Coast to the Rocky Mountains within the five northwestern states of the contiguous United States. We analyzed the response of richness to structural complexity and energy covariates at each landscape. We found that (1) richness had a hump-shaped relationship with available energy across the northwestern United States, (2) the landscape-scale relationships between energy and richness were positive or hump shaped in energy-limited locations and were flat or negative in energy-rich locations, (3) forest structural complexity explained more of the variation in bird species richness in energy-rich landscapes, and (4) the slope of the relationship between forest structural complexity and richness was steepest in energy-limited locations. In energy-rich locations, forest managers will likely increase landscape-scale bird diversity by providing a range of forest structural complexity across all seral stages. In lowenergy environments, bird diversity will likely be maximized by managing local high-energy hotspots judiciously and adjusting harvest intensities in other locations to compensate for slower regeneration rates.

Key words: birds; diversity; energy; forest structure; hotspot; landscape; managed forests; Pacific Northwest; productivity; richness.

\section{INTRODUCTION}

Managing for biodiversity is widely considered to be important for the preservation of ecosystem services such as clean air, clean water, soil fertility, and human disease prevention (Noss 1983, Tilman et al. 1997, McCann 2000). Thus, maintenance of biodiversity is a common goal of the managers of public and private forests of the northwestern United States (Loehle et al. 2002, Wilson and Puettmann 2007). Few guidelines exist, however, for how biodiversity response to forest management may differ among ecosystems arrayed along gradients in climate and primary productivity

Manuscript received 21 May 2007; revised 7 December 2007; accepted 24 January 2008. Corresponding Editor: R. L. Knight.

${ }^{4}$ E-mail: jverschuyl@yahoo.com
(A. J. Hansen, L. Baril, J. Watts, F. Kasmer, T. Ipolyi, R. Winton, unpublished manuscript). Current literature on species-energy relationships suggests that biodiversity varies with energy levels (i.e., climate factors relating to heat, light and primary productivity [Currie 1991, Mittlebach et al. 2001, Hawkins et al. 2003, Hurlbert 2004]), and that the effect of forest structure on biodiversity may vary with the level of available energy (Hansen et al. 2003). Research efforts have not evaluated the varying role of forest structure in driving biodiversity in the energetically diverse forests of the northwestern United States (Ishii et al. 2004, Sallabanks and Arnett 2005).

Vegetation structure refers generally to the horizontal and vertical distribution of vegetation. MacArthur and MacArthur (1961) refined the broad concept of vegetation structure by defining foliage height diversity as a 
measure of canopy layering, and suggesting its use as an indicator of biodiversity. Foliage height diversity recognizes the importance of the number and evenness of canopy layers (MacArthur and MacArthur 1961). Variations on the foliage height diversity concept have led to the development of several indices of forest structural complexity incorporating vertical and horizontal variation in tree size, canopy cover, shrub size, shrub cover, coarse woody debris, and snags (McElhinny et al. 2005). Vertical and horizontal structural complexity drives biodiversity by creating a greater variety of microclimates and microhabitats, which in turn produce more diverse food and cover for a more diverse group of species (MacArthur and MacArthur 1961, Carey et al. 1999, Hunter 1999).

In natural forests, structural complexity is modified by succession processes across seral stages (Oliver and Larson 1990, Spies and Franklin 1991, Spies 1998). Structural complexity is often intermediate in early seral stages as a legacy of disturbance. Canopy closure reduces the number of canopy layers in the understory, and decomposition reduces the abundance of residual standing and fallen dead trees, hence structural complexity decreases in intermediate successional stages. Structural complexity then rebuilds in mature and oldgrowth stages due to gap formation processes and the death of large trees (Spies and Franklin 1991, Spies 1998). Plant species richness in natural forests is thought to mirror the patterns of structural complexity, being highest in early- and late-seral forests and lowest in midseral stages (Franklin and Spies 1991, Halpern and Spies 1995). Bird species specialize on particular seral stages due to the unique characteristics of forest structure that exist within each stage (Sallabanks et al. 2002, 2006).

Traditional forestry practices such as clear-cutting tend to reduce structural complexity across all seral stages; hence these forests are often lower in structural and biological diversity when compared to naturally disturbed forests (Hansen et al. 1991). Therefore, managing for biodiversity within stands includes maintaining variation in tree size, multiple canopy layers, presence of coarse woody debris, and other elements of forest structural complexity within stands, in balance with wood production needs (Hunter 1999, Rapp 2004). Across landscapes, biodiversity managers strive to maintain a variety of seral stages, most commonly using a shifting mosaic approach (Loehle et al. 2002).

Ecologists working at regional to global scales converged on a different set of factors driving biodiversity. Many studies documented strong associations between available energy (factors relating to heat and ecological productivity) and species diversity, typically at continental to global scales (for reviews see Hansen and Rotella 1999, Irwin 1999, Waide et al. 1999, Mittelbach et al. 2001). Available energy, which sets fundamental limits on ecosystem properties such as energy flow, nutrient cycling, and disturbance regimes, also influences the composition of native species and communities. Community diversity has been found to be strongly associated with available energy such as potential evapotranspiration, temperature, precipitation, and primary productivity (Waide et al. 1999, Mittelbach et al. 2001, Chase and Leibold 2002, Hawkins et al. 2003, Bailey et al. 2004). The primary mechanism by which available energy it thought to lead to higher levels of species diversity is labeled the "more individuals hypothesis" (Hurlbert 2004, Monkkonen et al. 2006). This hypothesis suggests that higher levels of heat, energy, or greater food resources through enhanced ecosystem productivity allow more individuals in populations, fewer population extinctions, and more species in a community (see also Bonn et al. 2004).

Much debate exists over the shape of the energydiversity relationship, including the effects of spatial scale, species life-history traits, and the specific measures of energy used for analysis (Waide et al. 1999, Mittelbach et al. 2001, Chase and Leibold 2002). Most studies have incorporated regional, continental, or global extents, and have found positive or hump-shaped relationships between diversity measures and available energy (Mittelbach et al. 2001). The downturn in richness at the highest levels of available energy has been shown at both regional and continental scales, and is thought to be due to interspecific competition (Waide et al. 1999). Often in highly productive systems with lengthy inter-disturbance periods, a few species come to dominate the community, leading to reduced species richness (Huston 2004). Previous research conducted across the northwestern United States provides evidence of a hump-shaped energy-diversity relationship at the regional scale (Hansen et al. 2003). Energy-diversity relationships have not been widely examined at landscape scales, and the extent to which energy may modify the structural complexity-diversity relationship is not known.

Previous studies have emphasized the need for structure-focused management to retain high levels of species diversity across all forest types in the northwestern United States (Harris 1984, Kohm and Franklin 1997). We suggest that species diversity reflects an interaction between vegetation structure and available energy, and that the specific factors that limit species diversity likely vary across biophysical gradients. In productive environments, where energy is less limiting, we predict that structural complexity is primary in limiting species diversity. In contrast, we predict that structural complexity is secondary to energy in limiting species diversity in low-energy environments. In cold or dry systems, energy limitations may constrain diversity such that even the most structurally complex habitats have few species. Thus, the proportion of the total variation in species diversity explained by structural complexity may decrease where energy is the primary limiting factor. It follows that the slope of the relationship between species diversity and structural complexity may be less steep in energy poor environ- 
TABLE 1. Characteristics of study landscapes.

\begin{tabular}{|c|c|c|c|c|c|}
\hline Location & $\begin{array}{l}\text { Elevation } \\
\text { range }(\mathrm{m})\end{array}$ & $\begin{array}{l}\text { Annual } \\
\text { precipitation } \\
(\mathrm{cm})\end{array}$ & $\begin{array}{l}\text { Dominant } \\
\text { tree species }\end{array}$ & Land ownership & Structural conditions \\
\hline Coast Range & $0-968$ & $150-300$ & $\begin{array}{l}\text { western hemlock (Tsuga } \\
\text { heterophylla) }\end{array}$ & $\begin{array}{l}\text { primarily national } \\
\text { forest }\end{array}$ & $\begin{array}{l}\text { mostly second and third } \\
\text { growth, with a wide variety } \\
\text { of structural conditions }\end{array}$ \\
\hline Springfield & $300-1000$ & $120-200$ & $\begin{array}{l}\text { Douglas-fir (Pseudotsuga } \\
\text { menziesii) }\end{array}$ & $\begin{array}{l}\text { Weyerhaeuser with } \\
\text { some BLM and } \\
\text { USFS }\end{array}$ & $\begin{array}{l}\text { mostly second and third } \\
\text { growth, with a wide variety } \\
\text { of structural conditions }\end{array}$ \\
\hline Cle Elum & $600-1800$ & $50-200$ & $\begin{array}{l}\text { western hemlock, Pacific } \\
\text { silver fir (Abies amabilis), } \\
\text { grand fir (Abies grandis), } \\
\text { ponderosa pine (Pinus } \\
\text { ponderosa) }\end{array}$ & $\begin{array}{l}\text { Plum Creek Timber } \\
\text { Co. and USFS } \\
\text { (checkerboard) }\end{array}$ & $\begin{array}{l}\text { mostly second growth, } \\
\text { increased structural retention } \\
\text { especially on federal lands }\end{array}$ \\
\hline Gold Fork & $1200-2700$ & $50-150$ & $\begin{array}{l}\text { ponderosa pine, grand fir, } \\
\text { subalpine fir (Abies } \\
\text { lasiocarpa) }\end{array}$ & $\begin{array}{l}\text { Forest Capital } \\
\text { Partners (formerly } \\
\text { Boise Corporation) } \\
\text { and USFS }\end{array}$ & $\begin{array}{l}\text { green tree retention and } \\
\text { shelterwood cutting, with } \\
\text { shallow soils that lead to } \\
\text { a naturally patchy landscape }\end{array}$ \\
\hline Yellowstone & $1800-2700$ & $70-150$ & $\begin{array}{l}\text { lodgepole pine } \\
\quad(\text { Pinus contorta })\end{array}$ & USFS & $\begin{array}{l}\text { dense stands of mature trees, } \\
\text { with little understory, and } \\
\text { clearcuts with saplings and } \\
\text { small shrubs }\end{array}$ \\
\hline
\end{tabular}

ments. In other words, bird richness will increase less rapidly with increases in structural complexity in energy poor environments because species are more limited by food than by microhabitat.

If this hypothesis is correct, there are important implications for management. Maintenance of forest structure within a shifting mosaic harvest scheme is likely to be effective in high-energy environments. In low-energy environments, species diversity is often concentrated in localized areas of relatively high energy (Hansen and Rotella 2002, Bailey et al. 2004). Identifying and managing these diversity hot spots judiciously may be critical for maintaining species diversity in these landscapes.

The northwestern United States has strong gradients in climate, topography, and soils. Thus, forest productivity ranges from among the highest in North America west of the Cascade Crest, to very low in the cold continental setting on the east slopes of the Rocky Mountains. In this study, we use total native land bird species richness (hereafter referred to as species richness) to test our predictions about biodiversity. Birds are a suitable taxonomic group for this study for several reasons. Birds are well understood ecologically and taxonomically, and represent a range of feeding guilds and habitat niches (Erdelen 1984, O’Connell et al. 2000). Furthermore, birds represent the only taxonomic group that has been sampled sufficiently across the study landscapes to allow for these fine-scale analyses. Species richness is a simple way to represent regional diversity (Magurran 1988), and bird species richness has proven to be a valuable indicator of overall biodiversity (Furness and Greenwood 1993). However, there is often specific interest in subsets of species such as species at risk, or certain foraging or nesting guilds. We tested the hypotheses for both native land bird richness and for sensitive species richness. Results were similar for these two measures of biodiversity. We only report species richness here to allow a clearer presentation.

The goal of this paper is to examine the effects of energy on species richness within and across landscapes in the northwestern United States, and examine how the effect of forest structure on species richness changes with energy level. We used a combination of species richness biodiversity data, satellite data representing available energy, and field measurements of forest structure from five study landscapes distributed across the climatic gradient of the northwestern United States to test several hypotheses: (1) species richness exhibits a threshold or hump-shaped relationship with energy across all landscapes in the study region; (2) the relationship between available energy and species richness at the landscape-scale is positive in energylimited landscapes and flat or decreasing within energyrich landscapes; (3) forest structural complexity explains a lower percentage of the variation in species richness in energy-limited landscapes and a higher percentage in energy-rich landscapes; (4) the slope of the relationship between forest structural complexity and species richness is greatest in energy-rich landscapes.

\section{Methods}

\section{Study areas}

We selected five study landscapes to span the gradient of available energy that exists in managed forest lands of the northwestern United States (Table 1; Fig. 1). Landscape selection emphasized ownerships where land managers had biodiversity management objectives, and locations where existing data might supplement our sampling efforts. Three of the five study landscapes center on forest industry planning areas, including some 


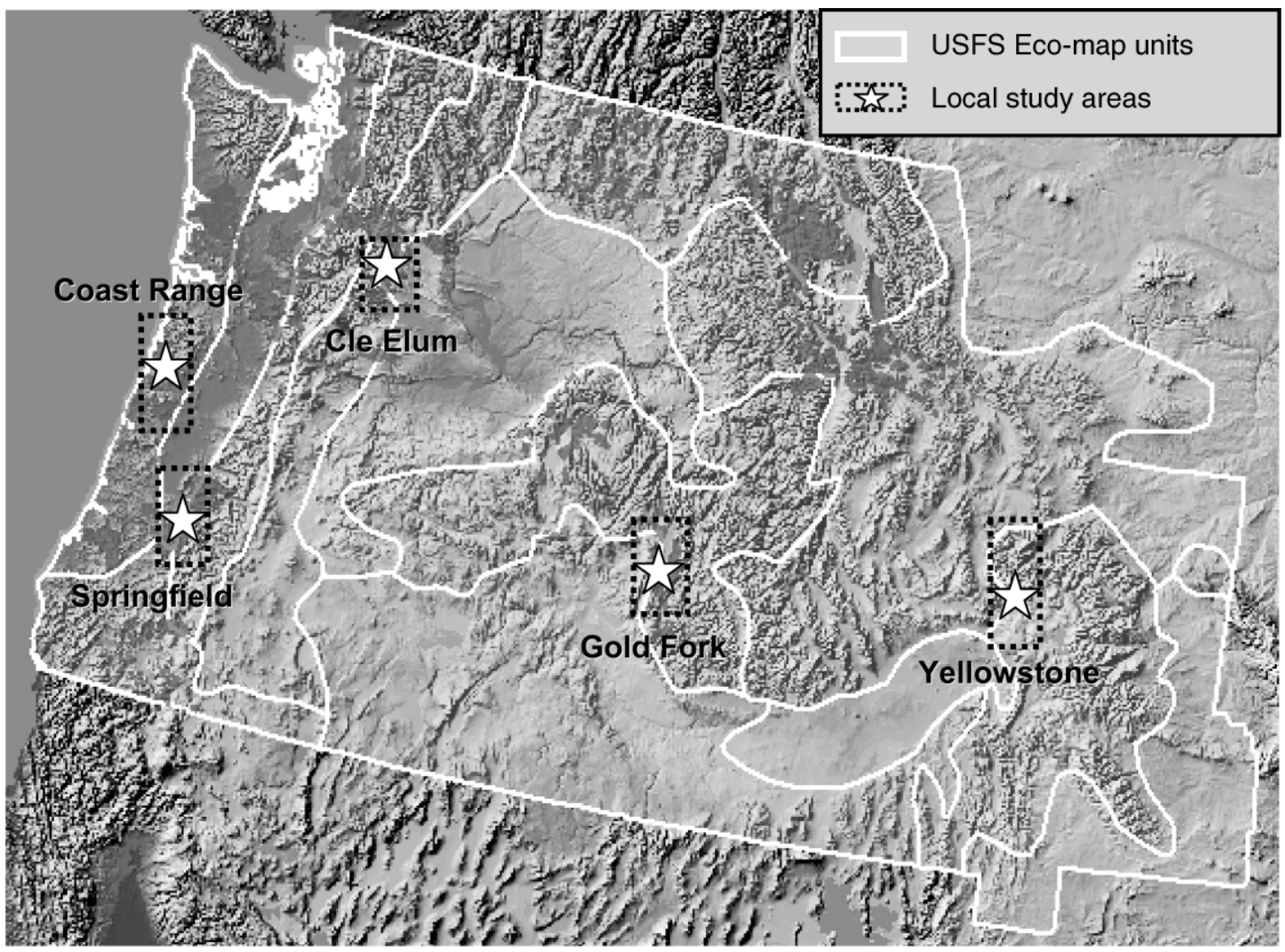

FIG. 1. Locations of study landscapes in the northwest United States.

surrounding portions of the ecoregion for which bird data were available. These landscapes include Springfield and Cottage Grove Tree Farms (here after referred to as Springfield) on the west slope of the Oregon Cascades (Weyerhaeuser Co.); the Central Cascades Habitat Conservation Area (here after referred to as Cle Elum) on the eastern slope of the Washington Cascades (Plum Creek Timber Co.); and the Gold Fork watershed in the southern Idaho batholith. The Coast Range and Yellowstone landscapes were selected to represent the extremes of the biophysical gradient in the region. Existing bird diversity data were used to complete analyses for the Coast Range and Yellowstone land- scapes (McGarigal and McComb 1995, Hansen et al. 2000). Data were collected across the gradients of energy and forest structure at each of the five study landscapes. A more-detailed description of specific locations and landscape attributes is included in Table 1.

\section{Sampling methods}

Bird and stand structure data were collected or compiled within stands stratified by stand age/structure class and stand vegetation/habitat class/site index (representing available energy) (Table 2). The objective of sample stratification was to have biodiversity samples across the full gradients of forest structural complexity

TABLE 2. Generic matrix of sampling categories. Matrix values (x) correspond to the number of stands (4-6 points each) needed to sample at least 20 points in each category.

\begin{tabular}{|c|c|c|c|c|}
\hline \multirow{2}{*}{$\begin{array}{l}\text { Gradient of available } \\
\text { energy (dominant vegetation } \\
\text { type, habitat class, } \\
\text { or site index) }\end{array}$} & \multicolumn{4}{|c|}{ Forest structure/seral stage gradient } \\
\hline & $\begin{array}{c}\text { Shrub sapling/ } \\
\text { "clearcut" } \dagger\end{array}$ & $\begin{array}{l}\text { Small tree/ } \\
\text { "pole" } \$\end{array}$ & $\begin{array}{c}\text { Medium tree/ } \\
\text { "mature"§ }\end{array}$ & $\begin{array}{l}\text { Large tree/ } \\
\text { "old-growth" }\end{array}$ \\
\hline Low & $\mathrm{x}$ & $\mathrm{x}$ & $\mathrm{x}$ & $\mathrm{x}$ \\
\hline Medium-low & $\mathrm{x}$ & $\mathrm{x}$ & $\mathrm{x}$ & $\mathrm{x}$ \\
\hline Medium-high & $\mathrm{x}$ & $\mathrm{x}$ & $\mathrm{x}$ & $\mathrm{x}$ \\
\hline High & $\mathrm{x}$ & $\mathrm{x}$ & $\mathrm{x}$ & $\mathrm{x}$ \\
\hline
\end{tabular}

$\dagger 0-2$ inches $(\sim 0-5 \mathrm{~cm})$ quadratic mean tree diameter (QMD) east and west.

$\$ 2-9$ inches $(\sim 5-22.5 \mathrm{~cm})$ QMD east; $2-10$ inches $(\sim 5-25 \mathrm{~cm})$ QMD west.

$\S 9-16$ inches $(\sim 22.5-40 \mathrm{~cm})$ QMD east; $10-21$ inches $(\sim 25-52.5 \mathrm{~cm})$ QMD west.

$\uparrow>16$ inches $(>40 \mathrm{~cm})$ QMD east; $>21$ inches $(>52.5 \mathrm{~cm})$ QMD west. 
and available energy, allowing meaningful tests of our hypotheses. Bird diversity data were generated from bird point-count data collected at four to six points (depending on the landscape) within each stand.

Within each landscape, data from four or more stands were obtained within each of four forest growth stages (structural/seral stage gradient) and three to five vegetation type, habitat class, or site index classes (energy gradient). The exception was the Yellowstone landscape where data were available for only two seral stages. The amount of structural complexity left in a stand following harvest varies with management prescription. We did not attempt to sample across the range of possible stand structures within harvest units. Instead, we sampled the types of harvest units that were typical in each landscape. Thus, we examined the effect of structure across, rather than within, seral stages.

The stratification of samples based on seral-stage categories were separated by quadratic mean tree diameter (QMD) cutoff values adapted from Oliver et al. (1995). The QMD cutoff values differed for landscapes west or east of the Cascade crest based on structural classifications provided in Brown (1985) for west-side forests, and Thomas (1979) for east-side forests. The QMD categories were lower and narrower in east side forests where the total variation in QMD is less (Table 2). To represent the energy gradient, we initially selected samples based on site index, habitat type, or vegetation class, which integrate climate, topography, and soils and are highly correlated with productivity. Once census point locations were acquired, we confirmed that they represented the full gradient of available energy by plotting the values of gross primary productivity for each sample point and comparing the distribution with the full range of the local energy gradient. The energy stratification classes varied among landscapes as determined by local habitat types.

The methods included below pertaining to the collection of bird and forest structure data are relevant only to Springfield, Cle Elum, and upper elevations of Gold Fork. However, data collection methods were quite similar in the Coast Range, Yellowstone, and lower elevations of the Gold Fork landscape where we relied on existing data sets to complete regional analyses. For specific information on the data collection methods of data contributors please see McGarigal and McComb ([1995] Coast Range), Hansen et al. ([2000] Yellowstone), and Sallabanks et al. ([2006] Gold Fork lower elevations).

Bird data.-We sampled birds at Springfield, Cle Elum, and upper elevations of the Gold Fork during the breeding season in 2003, 2004, and 2005, with two years of sampling completed at each bird census point. Four to six bird census points were used to represent a forest stand and were positioned along a transect with 150 200-m separation between adjacent points. During each survey year, points were sampled three times during the breeding season (15 May-10 July).
The ample number of surveys used to represent each stand increased the likelihood that rare birds with low detectability would still be adequately sampled. The survey order and observer were varied throughout the season to avoid associated biases. The variation in transect length and point spacing depended on the conditions of the landscape being surveyed and the protocol of any existing data sets that we were matching.

The manner in which data were recorded was consistent with the point count survey guidelines described by Ralph et al. (1995) within a 10-minute time interval. Every bird seen or heard was recorded with an associated first detection distance from the census point. Analysis of detection probabilities using the program DISTANCE (Thomas et al. 2002) revealed that approximately $80 \%$ of species were fully detectable within a $50 \mathrm{~m}$ radius. For the species that were not fully detectable, we examined if detectability varied between habitat types or seral stage. We found that detectability for these species was not biased by habitat type or seral stage. In addition, species with low detectability were not disproportionately associated with any particular habitat type or seral stage. Therefore, there was no need to adjust species abundance for detectability to estimate species richness. Species richness was calculated as the total number of bird species detected at each survey point over the three breeding season visits averaged across the four to six points and two years of surveys to represent a stand.

In addition to the bird data we collected, we used data previously collected by other investigators for the Coast Range, lower elevations at the Gold Fork, and for the Yellowstone site. Each of these previous studies used similar data collection methods for birds (e.g., 10-minute fixed-radius point counts) and vegetation.

Forest structure data.-We sampled vegetation at each point-count station once during the two years of survey work. To capture characteristics of the entire survey stand we established four subplots $20 \mathrm{~m}$ from each of the four to six survey stations in the four cardinal directions. Within each of the four subplots, attributes were measured within either a $0.25-\mathrm{m}^{2}$ subplot located $2 \mathrm{~m}$ north of the center of each plot, or within a 2,4 , or $8 \mathrm{~m}$ radius around the subplot center (Table 3). Data collected during vegetation surveys resulted in 28 predictors representing the variation in size and horizontal distribution of trees, shrubs, and snags, as well as canopy and understory measures (Table 3 ).

Energy data.-We examined several measures of energy as predictors of species richness. These included estimates of primary productivity derived at a $1-\mathrm{km}$ resolution by the MODIS satellite sensor (Running et al. 2004) including net primary productivity (NPP; g $\mathrm{C} \cdot \mathrm{m}^{-2} \cdot \mathrm{d}^{-1}$ ), gross primary productivity (GPP; g $\mathrm{C} \cdot \mathrm{m}^{-2} \cdot \mathrm{d}^{-1}$ ), and normalized difference vegetation index (NDVI), which is correlated with the fraction of photosynthetically active radiation (fPAR), leaf area index, and total green biomass. Potential productivity 
TABLE 3. Forest structure predictors (stand description measurements) and area of inventory.

\begin{tabular}{|c|c|c|}
\hline Forest structure predictor & Definition & $\begin{array}{l}\text { Inventory } \\
\text { plot size } \uparrow\end{array}$ \\
\hline \multicolumn{3}{|l|}{ Understory cover } \\
\hline Total & $\begin{array}{l}\text { percentage of understory cover total recorded as a } \\
\text { decimal }\end{array}$ & $0.25 \mathrm{~m}^{2}$ \\
\hline Coniferous & $\begin{array}{l}\text { percentage of understory cover that is conifer recorded } \\
\text { as a decimal }\end{array}$ & $0.25 \mathrm{~m}^{2}$ \\
\hline Deciduous & $\begin{array}{l}\text { percentage of understory cover that is deciduous } \\
\text { recorded as a decimal }\end{array}$ & $0.25 \mathrm{~m}^{2}$ \\
\hline Herbaceous & $\begin{array}{l}\text { percentage of understory cover that is herbaceous } \\
\text { recorded as a decimal }\end{array}$ & $0.25 \mathrm{~m}^{2}$ \\
\hline \multicolumn{3}{|l|}{ Diameter and density of shrubs } \\
\hline No. shrub basal classes & $\begin{array}{l}\text { number of basal diameter classes of trees in all } \\
\text { subplots at a given point }\end{array}$ & $2 \mathrm{~m}$ radius \\
\hline Mean shrub basal diameter & $\begin{array}{l}\text { derived from midline values in each of eight basal } \\
\text { diameter categories }\end{array}$ & $2 \mathrm{~m}$ radius \\
\hline Large shrub density & number of shrubs larger than $2 \mathrm{~cm}$ basal diameter & $2 \mathrm{~m}$ radius \\
\hline Shrub density & number of shrubs per point & $2 \mathrm{~m}$ radius \\
\hline Horizontal variation in large shrub density & $\begin{array}{l}\text { SD of the number of large shrubs (shrubs }>2 \mathrm{~cm} \text { basal } \\
\text { diameter) across four subplots }\end{array}$ & $2 \mathrm{~m}$ radius \\
\hline Horizontal variation in shrub density & SD of the number of shrubs across four subplots & $2 \mathrm{~m}$ radius \\
\hline \multicolumn{3}{|l|}{ Diameter and density of trees and saplings } \\
\hline No. tree diameter classes & mean number of dbh categories of trees per point & $8 \mathrm{~m}$ radius \\
\hline Quadratic mean tree diameter & quadratic mean tree diameter (in inches) $\$$ & $8 \mathrm{~m}$ radius \\
\hline Mean tree dbh & $\begin{array}{l}\text { derived from midline values in each of eight dbh } \\
\text { categories }\end{array}$ & $8 \mathrm{~m}$ radius \\
\hline Large tree density & mean number canopy layer trees $>50 \mathrm{~cm} \mathrm{dbh}$ & $8 \mathrm{~m}$ radius \\
\hline Mature tree density & mean number of canopy layer trees $>20 \mathrm{~cm} \mathrm{dbh}$ & $8 \mathrm{~m}$ radius \\
\hline Tree density & mean number of trees $(>2 \mathrm{~cm} \mathrm{dbh})$ per point & $8 \mathrm{~m}$ radius \\
\hline Horizontal variation in mature tree density & SD of the number of canopy layer trees $(>20 \mathrm{~cm} \mathrm{dbh})$ & $8 \mathrm{~m}$ radius \\
\hline Sapling density & $\begin{array}{l}\text { mean number of sapling trees }(<2 \mathrm{~cm} \mathrm{dbh}) \text { across four } \\
\text { subplots }\end{array}$ & $4 \mathrm{~m}$ radius \\
\hline Shade-tolerant sapling density & $\begin{array}{l}\text { total number of shade-tolerant saplings }(<2 \mathrm{~cm} \mathrm{dbh}) \\
\text { at all four subplots }\end{array}$ & $4 \mathrm{~m}$ radius \\
\hline Large snag density & number of snags $>20 \mathrm{~cm}$ dbh per point & $4 \mathrm{~m}$ radius \\
\hline Snag density & mean number of snags per point & $8 \mathrm{~m}$ radius \\
\hline Volume of coarse woody debris & volume $\left(\mathrm{m}^{3} / \mathrm{ha}\right)$ per point $\S$ & $4 \mathrm{~m}$ radius \\
\hline \multicolumn{3}{|l|}{ Size diversity } \\
\hline Tree size diversity & $\begin{array}{l}\text { mean Shannon-Weiner tree size diversity calculations } \\
\text { (across four subplots) }\end{array}$ & $8 \mathrm{~m}$ radius \\
\hline Horizontal variation in tree size diversity & SD of tree size diversity across four subplots & $8 \mathrm{~m}$ radius \\
\hline Structural complexity index & $\begin{array}{l}\text { tree size diversity } \times \text { the horizontal variation in tree } \\
\text { size diversity among subplots } \times 100\end{array}$ & $8 \mathrm{~m}$ radius \\
\hline Canopy closure & percent canopy closure & 80 points \\
\hline Horizontal variation in canopy cover & $\begin{array}{l}\text { SD of the percent canopy cover measured across four } \\
\text { subplots }\end{array}$ & 80 points \\
\hline
\end{tabular}

$\dagger$ For all predictors, the inventory consisted of 20 plots of the area or radius specified, except for canopy closure and canopy horizontal cover, measured by densiometer at points.

$\$$ Calculated as $\sqrt{\left(\sum_{i=1}^{n}[\mathrm{dbh}]_{i}^{2}\right) / n}$ where $n=$ the total number of trees and $i=$ individual tree.

$\S$ Calculated as $V=L \times\left(D^{2}+d \times D+d^{2}\right) \times(\pi / 12)$ where $V=$ volume, $D=$ diameter at large end, $d=$ diameter at small end, and $L$ $=$ length.

$-\Sigma\left(p_{i}\left[\ln \left(p_{i}\right)\right]\right)$ where $p_{i}=$ proportion of trees in size class $i$.

was represented by climate variables relating to precipitation, temperature, solar radiation as derived by the DAYMET model (Thornton et al. 1997; Table 4). Accuracy assessments of remotely sensed energy and productivity predictors are included in Heinsch et al. (2003, 2006). Productivity data were averaged over the years 2000-2005 to correspond with the bird sampling. The portion of the annual energy cycle that is most strongly related to species richness is not well known.
Thus, we summarized the productivity and climate data during the breeding season (May and June), plant growing season (April-September), and annually. Climate data were averages for 1982-2000. Elevation data were gathered from a $10-\mathrm{m}$ resolution digital elevation model, and information on slope, aspect, and slope position were gathered in the field during the vegetation surveys. The predictor variables were categorized for analysis as shown in Table 4. 
TABLE 4. Remotely sensed predictor data required in the study listed by category, variable, source, and the methods of data collection.

\begin{tabular}{|c|c|c|c|c|}
\hline Category & Predictor variable & $\begin{array}{l}\text { Resolution/ } \\
\text { scale }\end{array}$ & $\begin{array}{c}\text { Source and } \\
\text { years sampled }\end{array}$ & $\begin{array}{l}\text { Time period } \\
\text { represented }\end{array}$ \\
\hline Topography & elevation & $10 \mathrm{~m}$ & $\begin{array}{l}\text { USGS seamless source: } \\
10 \text {-m digital elevation } \\
\text { model }\end{array}$ & NA \\
\hline Climate & $\begin{array}{l}\text { precipitation, temperature, } \\
\text { vapor pressure deficit, solar } \\
\text { radiation, frost, and growing days }\end{array}$ & $1 \mathrm{~km}$ & $\begin{array}{l}\text { DAYMET source: } \\
\text { (remodeled) } 18 \text { years } \\
\text { averaged (1982-2000) }\end{array}$ & $\begin{array}{l}\text { annual, April } \\
\text { through September, } \\
\text { and May/June } \\
\text { measurements for } \\
\text { all predictors }\end{array}$ \\
\hline $\begin{array}{l}\text { Vegetation } \\
\text { productivity }\end{array}$ & $\begin{array}{l}\text { NDVI (normalized difference } \\
\text { vegetation index), GPP } \\
\text { (gross primary productivity) } \dagger, \\
\text { growing season index }\end{array}$ & $1 \mathrm{~km}$ & $\begin{array}{l}\text { MODIS source: } \\
\text { NDVI = 3-year mean } \\
(2003-2005) \text { GPP and } \\
\text { NPP }=5 \text {-year mean } \\
(2000-2004)\end{array}$ & $\begin{array}{l}\text { NDVI }=3 \text { single-day } \\
\text { measurements and a } \\
\text { breeding season average; } \\
\text { GPP and NPP = mean } \\
\text { annual measures }\end{array}$ \\
\hline
\end{tabular}

Note: NA, not applicable.

$\dagger$ Heinsch et al. (2003).

\section{Data analysis}

Available energy and species richness.-Hypothesis 1 on energy and species richness across the northwestern U.S. region was examined by first assessing which productivity and climate variables and temporal periods were most strongly related to species richness across all five landscapes. We felt it was important to assess the relationship between richness and the breeding season pulse of available energy, as well as an annual measure of energy. We found that breeding season NDVI and annual GPP produced the strongest univariate models. Thus, AIC values from linear, quadratic (unimodal), cubic (nonsymmetric unimodal), and threshold (breakpoint) linear models were compared to explain the relationship between species richness and both breeding season (NDVI) and annual (GPP) measures of available energy across the entire region (all five landscapes). Parsimonious interpretations of the models were selected when competing models were within 2 AIC units (Burnham and Anderson 1998).

To examine hypothesis 2 on slopes of relationships between energy predictors and species richness within each landscape, we examined the strength, slope, and significance of univariate relationships. The sample sizes within landscapes were insufficient to warrant fitting curvilinear models. Therefore, the positive or negative nature of the relationship between breeding season and annual measures of energy and species richness within each landscape was examined by creating simple linear models.

We compared the mean and standard deviation of breeding season (NDVI) and annual (GPP) measures of available energy at each of the five landscapes to investigate how much variation there was in available energy within each landscape, and how much overlap there was between landscapes.

Interaction of structure and energy in driving species richness.-In testing Hypothesis 3 on the relative strength of forest structural complexity and available energy in explaining richness at each of the five landscapes across the northwestern U.S. region, we first acknowledged that structural complexity will naturally covary with energy to some extent at all landscapes. To more cleanly separate the effect of structure and energy in driving species diversity at each landscape we removed the structure covariates that were highly correlated with measures of available energy from the interaction analysis. We found that covariates describing shrubs and understory cover were the only forest structure covariates that had consistently moderate correlations with measures of energy (45-60\% correlation) at most landscapes. We removed the shrub and understory cover covariates leaving 18 predictors of forest structure representing variation in the size and density of trees, snags, saplings, coarse woody debris, and canopy cover.

The 18 structural complexity predictors, and the entire suite of available energy (31) predictors, were used to test the relative strength of available energy and forest structural complexity in driving species richness at each landscape. Many of the predictors of forest structure and available energy were variations of the same measurement (e.g., annual precipitation vs. breeding season precipitation). To select the predictors with the most explanatory power from the large group of structure and energy covariates (many of which were redundant) for the interaction analysis, single predictors of forest structure and available energy were chosen to represent each of 10 distinct categories (Table 5). These categories were designed to represent the major components of the structure and energy gradients at each of the landscapes. In this way, we helped to insure that the suite of forest structure covariates used in the models for each landscape would have similar potential for explaining the variation in species richness, and minimized collinearity between redundant covariates. The 10 categories for structure and energy remained the same for each landscape, but the predictor selected (from the 
TABLE 5. Descriptive categories of forest structure and available energy.

\begin{tabular}{ll}
\hline \hline \multicolumn{1}{c}{ Forest structure } & \multicolumn{1}{c}{ Available energy } \\
\hline $\begin{array}{l}\text { Canopy cover } \\
\text { Horizontal variation in } \\
\text { canopy cover }\end{array}$ & Vapor pressure deficit \\
$\begin{array}{l}\text { Density of trees } \\
\text { Horizontal variation in } \\
\text { tree density }\end{array}$ & Frost days or growing days \\
$\begin{array}{l}\text { Size of trees } \\
\text { Horizontal variation in } \\
\text { tree size }\end{array}$ & Precipitation \\
$\begin{array}{l}\text { Density of snags } \\
\text { Size of snags }\end{array}$ & Normalized difference \\
Density of saplings & vegetation index \\
Coarse woody debris & Primary productivity \\
\hline
\end{tabular}

18 structural and 31 energy predictors) to represent the category was allowed to differ. For example, precipitation may be represented by the total precipitation in May and June at one landscape, but by annual precipitation at another landscape. In addition, selected predictors were allowed quadratic or cubic functional relationships when the resulting relationship with species richness was determined to be ecologically meaningful. This method allowed for a cumulative explanation of the strength of the relationship between forest structural complexity, available energy, and species richness at each landscape, which was not possible with other methods such as PCA, where the overall strength of relationship between richness and energy or forest structure would be driven most strongly by the orthogonality of selected predictors.

Energy explains the variation in species richness with varying strength at all landscapes. Therefore, to test the interaction of structural complexity with available energy in driving diversity at each landscape we needed to control for the effect of energy when assessing the strength of the relationship between structural complexity and species richness. To accomplish this, we calculated the additional explanatory power of forest structural complexity covariates when added to a five predictor energy model at each landscape. To compare additional explanatory power across several landscapes using $R^{2}$, the number of predictors used in the model at each site was held consistent. Therefore, we used five predictors to provide a balance between adequate representation of the energy and structure gradients and model parsimony. To create the five-predictor energy model, we selected the most significant univariate energy predictors $(P<0.05)$ from each of the 10 descriptive categories and included them in a stepwise model selection procedure (forward, backward, and exhaustive methods of variable selection) using the "regsubsets" function in the R statistical package (R Foundation for Statistical Computing, Vienna, Austria). Regsubsets uses $R^{2}$ as the criterion for best model selection, thus ensuring that the resulting energy model explained the highest level of variation possible using five predictors.

After creating the best five-predictor energy model for each landscape, we used the same automated model selection procedure to select the best 10-predictor model (five structure and five energy) while forcing the selected five-predictor energy model to be the base condition. Again, this process used $R^{2}$ as the criterion for model selection which ensured that the five structural complexity covariates added the most additional explanatory power possible, given the five energy predictors already in the model. We then compared the $R^{2}$ values of the five-predictor energy model to the 10-predictor structure and energy model to identify the additional explanatory power added by the structural complexity covariates. We tested for the potential effects of spatial autocorrelation of stands within each landscape and found that spatial autocorrelation terms were not significant in any of the models. The percentage of the total model $R^{2}$ corresponding with the addition of structural complexity covariates was compared descriptively across landscapes to weigh the evidence for a trend in the explanatory power of forest structure across the regional energy gradient. In addition, the model selection procedure was run in reverse, adding forest structure predictors to the model first and then comparing the percentage increases in model $R^{2}$ after adding five available energy covariates.

Hypothesis 4 on the slope of the relationship between forest structural complexity and species richness was examined by first comparing the strength and direction of simple relationships between forest structural complexity covariates and species richness at different landscapes. We condensed these analyses by identifying the three strongest (low $P$ value, high $R^{2}$ ) measures of structural complexity across all landscapes. These include Shannon diversity index (Shannon and Weaver 1949) of tree size classes (here after referred to as tree size diversity), percent shrub cover, and a structural complexity index of horizontal vertical variation in tree size and density (hereafter referred to as SCI and computed as [tree size diversity] $\times$ [SD of tree density between 20 subplots] $\times 100$ [Zenner and Hibbs 2000, McElhinney et al. 2005]).

To test our prediction that the slopes of forest structural complexity covariates would be steeper in high-energy environments, we investigated the slopes of significant linear relationships between species richness and SCI. The comparison of slopes required the stand structure data to have been collected with identical protocols (dbh class definitions, plot sizes, and so on). Therefore, we restricted the comparison to include only the Springfield, Cle Elum, and Yellowstone landscapes. We conducted a test of slopes $(b)$ using the formula

$$
t=\left(b_{1}-b_{2}\right) / \sqrt{\left[\operatorname{SE}\left(b_{1}\right)\right]^{2}+\left[\operatorname{SE}\left(b_{2}\right)\right]^{2}}
$$


TABLE 6. Available energy covariates for the five study landscapes.

\begin{tabular}{|c|c|c|c|c|c|c|c|c|c|c|}
\hline \multirow[b]{2}{*}{ Energy measure } & \multicolumn{2}{|c|}{ Coast Range } & \multicolumn{2}{|c|}{ Springfield } & \multicolumn{2}{|c|}{ Cle Elum } & \multicolumn{2}{|c|}{ Gold Fork } & \multicolumn{2}{|c|}{ Yellowstone } \\
\hline & Mean & SD & Mean & SD & Mean & SD & Mean & SD & Mean & SD \\
\hline 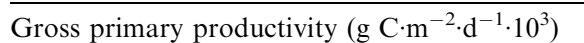 & 15133 & 719 & 14152 & 1184 & 9176 & 1241 & 7321 & 1176 & 5620 & 1152 \\
\hline $\begin{array}{l}\text { Breeding season NDVI (avg. highest } 0-1 \text { index } \\
\text { values from four periods, } 6 \text { May-26 June; } \\
\times 10^{4} \text { ) }\end{array}$ & 8576 & 231 & 8502 & 388 & 6911 & 739 & 6281 & 1067 & 4899 & 1169 \\
\hline Growing degree-days (annual sum) & 361.8 & 25.3 & 371.6 & 22.3 & 228.5 & 29.7 & 212.1 & 42.4 & 184.2 & 29.5 \\
\hline $\begin{array}{l}\text { Temperature (monthly average of annual } \\
\text { temp., }{ }^{\circ} \mathrm{C} \text { ) }\end{array}$ & 9.4 & 0.7 & 9.5 & 0.7 & 4.6 & 1.2 & 3.2 & 1.8 & 1.4 & 1.3 \\
\hline $\begin{array}{l}\text { Annual precipitation (monthly average of } \\
\text { annual precipitation, } \mathrm{cm} \text { ) }\end{array}$ & 19.2 & 1.3 & 13.4 & 2 & 11.8 & 4.5 & 7.9 & 1.7 & 7 & 1.5 \\
\hline
\end{tabular}

where $\mathrm{df}_{1}=n_{1}-1$ and $\mathrm{df}_{2}=n_{2}-1$, for all possible combinations.

\section{RESULTS}

\section{Variation in bird diversity}

Mean species richness was highest in Springfield, intermediate in Coast Range and Cle Elum, lower in Gold Fork, and lowest in Yellowstone (Fig. 2). Mean species richness was significantly different between all landscapes $(P<0.05)$ except for Coast Range and Cle Elum.

\section{Regional and landscape relationships between richness and energy: hypothesis 1 and 2}

Measures of energy were highest in the Springfield and Coast Range landscapes, and decreased to the east, with Yellowstone being lowest (Table 6). The standard deviation of energy covariates measure of the width of the energy gradient at each landscape and were typically higher in the Cle Elum, Gold Fork, and Yellowstone

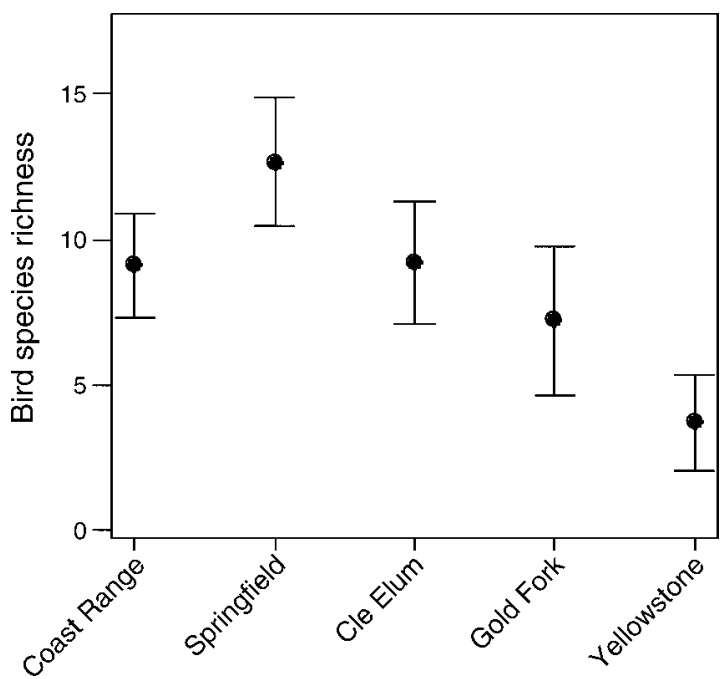

FIG. 2. Bird species richness by study landscape. Values are means \pm SD of the number of bird species detected within 50 $\mathrm{m}$, cumulative over three 10 -minute visits and averaged by year. landscapes, and lower in the Coast Range and Springfield landscapes (Table 6).

Species richness exhibited a threshold (breakpoint regression) relationship with the annual measure of available energy (GPP) and a cubic relationship with the breeding season measure of available energy (NDVI) across all five landscapes (Table 7, Fig. 3). The linear breakpoint model for annual GPP was substantially better $(\triangle \mathrm{AIC}=8.71)$ than the second-best model (quadratic GPP; Table 7). Geographically, the breakpoint of GPP = 12266 lay between the Cle Elum (east slope Cascades) and Springfield (west slope Cascades) landscapes. The slope after the breakpoint was negative $(P=0.082)$, showing a downturn in species richness for the two energy-rich landscapes west of the Cascade crest (Fig. 3). The relationship between breeding season energy and species richness did not show a negative trend at the highest energy values. Rather, the cubic model plateaued at about NDVI $=8000$. This model was not greatly better $(\triangle \mathrm{AIC}=3.25)$ than the second-best linear model with a breakpoint at NDVI $=8007$, suggesting some potential ambiguity on the reality of a downturn in richness in the most productive sites.

Species richness had negative relationships with breeding season NDVI at Coast Range and Springfield (Table 8). The remaining available energy predictors had

TABLE 7. Best regional univariate models of species richness using breeding season and annual measures of available energy (all landscapes).

\begin{tabular}{llll}
\hline \hline \multicolumn{1}{c}{ Energy models } & AIC & $\Delta \mathrm{AIC}$ & $R^{2}$ \\
\hline Breeding season NDVI & & & \\
$\quad$ Asymetric gradual threshold (cubic) & 1258.37 & 0 & 0.49 \\
$\begin{array}{l}\text { Specific threshold NDVI = 8007 } \\
\quad \text { (breakpoint) }\end{array}$ & 1261.62 & 3.25 & 0.48 \\
$\quad \begin{array}{llll}\text { Positive (linear) } \\
\text { Gradual threshold (quadratic) }\end{array}$ & 1269.81 & 11.44 & 0.46 \\
Annual GPP & 1269.94 & 11.57 & 0.46 \\
$\quad$ Specific threshold GPP =12266 & 1270.2 & 0 & 0.46 \\
$\quad$ (breakpoint) & 1278.91 & 8.71 & 0.44 \\
$\quad \begin{array}{l}\text { Gradual threshold (quadratic) } \\
\text { Asymmetric gradual threshold (cubic) }\end{array}$ & 1280.62 & 10.42 & 0.44 \\
$\quad$ Positive (linear) & 1301.77 & 31.57 & 0.39 \\
\hline
\end{tabular}

Note: Models are arranged in order from lowest AIC (best fit) to highest AIC. 
nonsignificant relationships with species richness at Coast Range and Springfield. Positive or unimodal relationships existed between species richness and available energy covariates at Cle Elum, Gold Fork, and Yellowstone. At Cle Elum, Gold Fork, and Yellowstone, precipitation was negatively correlated with species richness. Where precipitation was negatively correlated with species richness it was positively correlated with elevation $(P<0.001)$, and in the Gold Fork and Yellowstone landscapes, precipitation was negatively correlated with primary productivity $(P<$ $0.001)$.

\section{Interaction of structure and energy in driving species richness: hypotheses 3 and 4}

The $R^{2}$ values for available energy models used to predict species richness ranged from 0.30 in the Springfield landscape to 0.67 in the Yellowstone landscape (Table 9, Fig. 4). The available energy only models explained more of the variation in species richness in the three landscapes east of the Cascade crest. The addition of forest structure variables to the energy model explained more additional variation in species richness in the two western landscapes than the three to the east. When the analysis was reversed and the structural predictors were added to the model first, the energylimited landscapes east of the Cascade crest had a larger percentage of the total model $R^{2}$ associated with the addition of five available energy covariates (Table 10, Fig. 5).

Species richness exhibited positive (increasing) or unimodal (threshold) relationships with structural complexity predictors at all landscapes, except Springfield (Table 11). In the Coast Range, species richness had a positive relationship with SCI and a unimodal relationship with shrub cover. In Springfield, measures of overstory complexity (tree size diversity, SCI) were negatively related to species richness, but shrub cover was positively related to species richness (Table 11). SCI was positively related to species richness at Cle Elum and Yellowstone. In Gold Fork, species richness had a unimodal relationship with shrub cover and no correlation with either measure of overstory complexity.

The slope of the relationship between species richness and SCI varied in direction and strength between the three landscapes (Fig. 6). The Springfield landscape had a significant negative relationship between species richness and SCI $(P=0.011)$. The Cle Elum and Yellowstone landscapes both had significantly positive relationships between species richness and the structural complexity index. The slopes of the relationship at Springfield differed significantly from the slopes at the Cle Elum and Yellowstone landscapes (both $P<0.001$ ). The Cle Elum and Yellowstone slopes did not differ $(P=$ 0.82 ). The slope of the relationship between species richness and SCI was steeper in both Cle Elum and Yellowstone than it was in Springfield (Fig. 6).

\section{Discussion}

\section{Hypothesis 1: energy as a regional- and landscape-scale driver of species diversity}

The results supported our predictions that species richness is significantly related to available energy at both the landscape and regional level across the northwestern United States. At the regional level, the relationship between annual GPP and species richness exhibited a threshold, having a positive slope at Yellowstone, Gold Fork, and Cle Elum and a negative slope across Springfield and Coast Range. The threshold occurred between Cle Elum and Springfield, which suggests a notable difference in the way that species richness responds to additional energy between forested landscapes west and east of the Cascades. The cubic relationship between breeding season NDVI and species richness was generally positive but showed some leveling at the highest end of the regional energy gradient, suggesting a potential plateau in the beneficial effects of additional energy (Fig. 3). Further support for the leveling or downturn in species richness at the highest end of the regional energy gradient was found at the landscape level, where negative relationships between species richness and breeding season NDVI occurred at the two most energy-rich landscapes. Although several of the results suggest a downturn in species richness at the highest levels of available energy, factors other than the availability of energy itself may play a role in reducing species richness. Other potential explanations include forest structure and canopy closure differences inherent to specific landscapes, the distance from the coast, or the physiological limitations of vegetation that may result in an inability to utilize additional energy.

The strength and direction of the landscape level relationship between species richness and available energy match with the relationships that could be inferred by the landscape's location along the regional energy gradient (Fig. 3). In landscapes east of the Cascade crest (Cle Elum, Gold Fork, and Yellowstone), where the availability of resources may limit population processes, species richness was strongly and positively related to measures of available energy. In energy-rich landscapes west of the Cascade crest (Coast Range and Springfield) there were insignificant or negative relationships between measures of available energy and species richness. In addition, the result of the analyses conducted between sensitive species richness, GPP, and NDVI suggests that these results are applicable to nongeneralist species as well.

\section{Hypothesis 2: interaction of structure and energy}

Primary drivers of diversity.-The increase in variation of species richness explained by forest structure in more energy-rich landscapes, and the increase in variation of species richness explained by available energy in energy-limited landscapes provides evidence of the shifting drivers of diversity across the northwestern United States. Forest structure contributed little to 

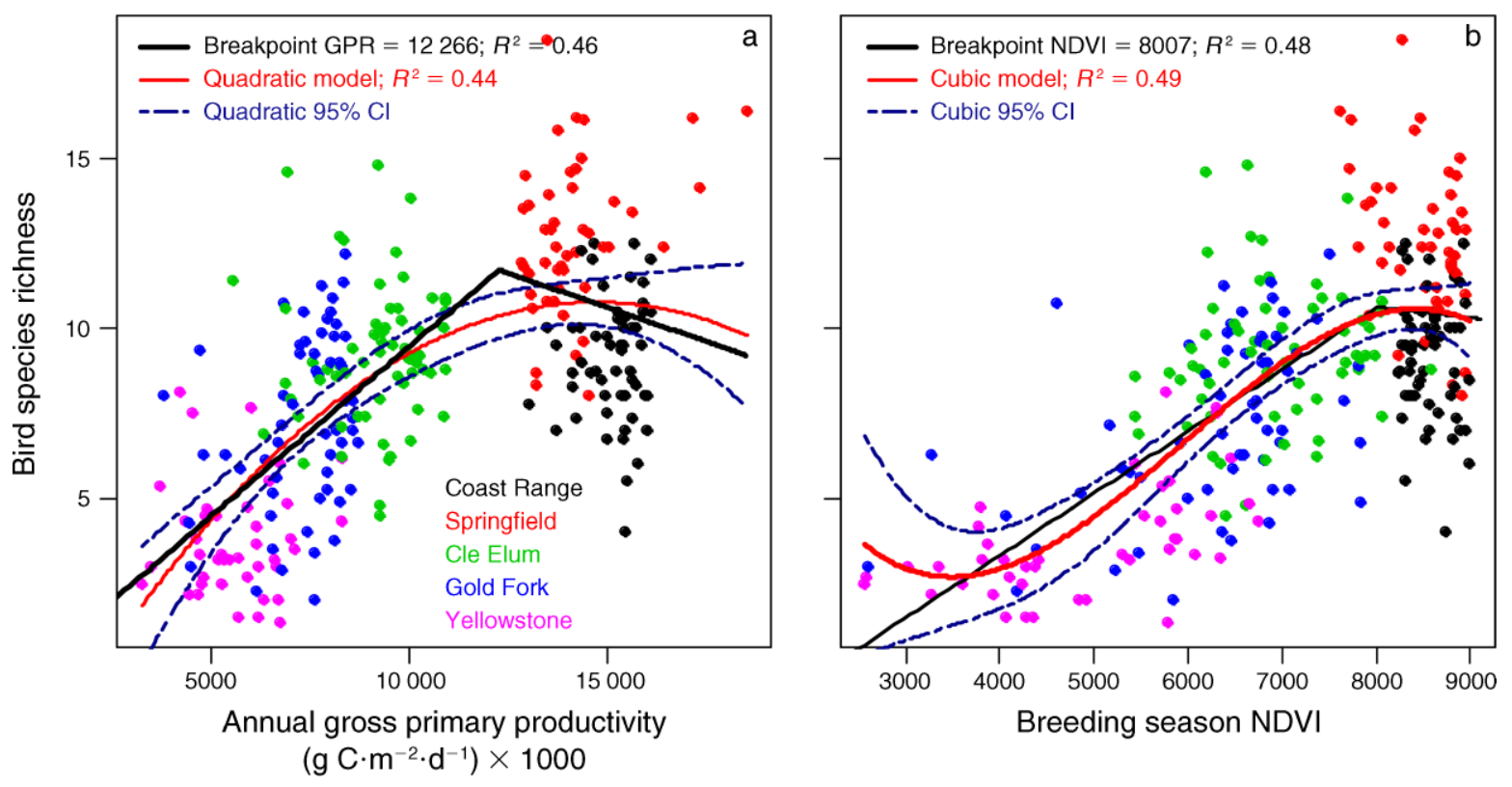

FIG. 3. Bird species richness across the northwest United States (color coded by landscape name) by (a) annual energy (gross primary productivity [GPP]), and (b) breeding season energy (normalized difference vegetation index [NDVI]). Best curvilinear (red lines with blue dashed confidence bands) and breakpoint regression (black lines) relationships are shown.

the $R^{2}$ of the species richness 10-predictor (energy-first) model in energy-limited landscapes, suggesting that energy at least partially overrides the impact of forest structural complexity in driving species richness in energy-limited landscapes. In addition, available energy contributed little to the $R^{2}$ of the species richness 10 predictor (structure-first) model in energy-rich landscapes. Recently published work from west-central Idaho, including the Gold Fork landscape included in our study, indicated that forest structure variables explained only $19 \%$ of the variation in species richness (Sallabanks et al. 2006). Such studies from energylimited landscapes suggest that considerable variation in species richness is explained by factors other than forest structure, such as energy and/or larger scale, landscapelevel features.

Slope of the species-richness-forest-structural-complexity relationship.-We found that the slope of the relationship between species richness and structural complexity was steepest in the Yellowstone landscape. This is in contrast to our prediction that slopes would be less steep in energy-poor locations. The Cle Elum and Yellowstone landscapes showed positive relationships between species richness and covariates representing forest structural complexity. However, in the Springfield landscape, we found that species richness did not increase with increasing overstory complexity. Unlike the other landscapes, species richness was higher in the shrub-sapling seral stage than older seral stages, which led to negative relationship between species richness and many measures of forest structural complexity. We speculate that higher levels of species richness in early seral stages in Springfield may be due to the high level of available energy and favorable conditions for rapid shrub and tree growth following timber harvest. More specifically, the energy-rich environment may help to produce the well developed and diverse shrub layer in

TABLE 8. Direction (Dir.) and significance (Sig.) of relationships between available energy and species richness for the five landscapes.

\begin{tabular}{|c|c|c|c|c|c|c|c|c|c|c|}
\hline \multirow[b]{2}{*}{ Energy measure } & \multicolumn{2}{|c|}{ Coast Range } & \multicolumn{2}{|c|}{ Springfield } & \multicolumn{2}{|c|}{ Cle Elum } & \multicolumn{2}{|c|}{ Gold Fork } & \multicolumn{2}{|c|}{ Yellowstone } \\
\hline & Sig. & Dir. & Sig. & Dir. & Sig. & Dir. & Sig. & Dir. & Sig. & Dir. \\
\hline Gross primary productivity & ns & & ns & & $* * *$ & $+($ cubic $)$ & $* * *$ & + (quadratic) & $* * *$ & + \\
\hline Breeding season NDVI & $*$ & - & ** & - & $* *$ & + & $* * *$ & + & $* * *$ & + \\
\hline Annual growing degree-days & ns & & ns & & $*$ & + (cubic) & $* * *$ & + (quadratic) & $* * *$ & + \\
\hline Annual temperature & ns & & $\mathrm{ns}$ & & $*$ & + (cubic) & $* * *$ & + (quadratic) & $* * *$ & + \\
\hline Annual precipitation & ns & & ns & & $* *$ & - & $*$ & - & $* * *$ & - \\
\hline
\end{tabular}

Notes: See Table 6 for units of measure. Direction is either positive (+) or negative $(-)$; if direction is not noted as cubic or quadratic, it is linear. Significance is: ns, not significant; $* P<0.05 ; * * P<0.01 ; * * * P<0.001$. 
TABLE 9. Predictors from the 10 best predictor energy-first models by landscape.

\begin{tabular}{|c|c|c|c|c|c|c|}
\hline Landscape & Model & & & redictors & & \\
\hline Coast Range & $\begin{array}{l}\text { energy } \\
\text { structure }\end{array}$ & $\begin{array}{l}\text { ndvil45 } \\
\text { stdev treecov }\end{array}$ & frosummj & frosummj $^{2}$ & tempavgas & radavgas \\
\hline Springfield & energy & ndvil 29 & nppmodis & vpdavgjja & gsi05 & preavgas \\
\hline Cle Elum & $\begin{array}{l}\text { structure } \\
\text { energy } \\
\text { structure }\end{array}$ & $\begin{array}{l}\text { trdiv } \\
\text { radavgas } \\
\text { num mtree }\end{array}$ & $\begin{array}{l}\text { trdiv }^{2} \\
\text { preavgan } \\
\text { num mtree }\end{array}$ & $\begin{array}{l}\operatorname{trdiv}^{3} \\
\text { preavgan } \\
\text { stdev.trdiv }\end{array}$ & $\begin{array}{l}\text { qmd } \\
\text { preavgan } \\
\text { stdev trdiv }{ }^{2}\end{array}$ & $\begin{array}{l}\text { st.complex } \\
\text { vpdavgann } \\
\text { st.complex }\end{array}$ \\
\hline Gold Fork & $\begin{array}{l}\text { energy } \\
\text { structure }\end{array}$ & $\begin{array}{l}\text { tempavgmj } \\
\text { num.sap }\end{array}$ & $\begin{array}{l}\text { ndviavgan } \\
\text { shade.sap }\end{array}$ & $\begin{array}{l}\text { ndviavg } \\
\text { canopy }\end{array}$ & $\begin{array}{l}\text { frosummj } \\
\text { canopy }^{2}\end{array}$ & $\begin{array}{l}\text { frosummj } \\
\text { lsnag }\end{array}$ \\
\hline Yellowstone & $\begin{array}{l}\text { energy } \\
\text { structure }\end{array}$ & $\begin{array}{l}\text { tempavgan } \\
\text { qmd }\end{array}$ & $\begin{array}{l}\text { ndvi129 } \\
\text { avg.dbh }\end{array}$ & $\begin{array}{l}\text { ndviavg } \\
\text { snpp }\end{array}$ & $\begin{array}{l}\text { ndviavgan } \\
\text { trdiv }\end{array}$ & $\begin{array}{l}\text { frosuman } \\
\text { num.58tree }\end{array}$ \\
\hline
\end{tabular}

Note: See Appendix for all predictor definitions.

the shrub-sapling seral stage in Springfield that is not present in other locations.

In high-energy locations, disturbance (in this case forest harvest) can act to break competitive dominance of certain plant species and free resources, making homogeneous forests more diverse (Huston 1994, 2004). In support of this hypothesis, D. B. McWethy, J. P. Verschuyl, and A. J. Hansen (unpublished manuscript) found that species richness was positively correlated with amount of disturbance in the surrounding landscape in Springfield; the opposite was true in Cle Elum. These findings point to the importance of early-seral habitats in energy-rich environments, where disturbance leads to reduced competitive plant dominance which appears to outweigh the benefit of increased structural complexity to bird diversity.

Similar analyses were conducted for sensitive species richness. The results of the analyses completed for sensitive species richness were similar to those completed for total species richness, suggesting that conclusions and management applications may be valid for other than simple alpha diversity.

\section{Related research}

Many studies have focused on the effects of energy in driving species diversity at local, continental, and global scales (Hansen and Rotella 1999, Irwin 1999, Waide et al. 1999, Mittelbach et al. 2001). Additionally, a large number of studies have investigated patterns of diversity at a local scale based on forest structural complexity or seral stage (Kohm and Franklin 1997, Carey 1998, Ishii et al. 2004, Sallabanks et al. 2006). The effects of energy and habitat on diversity differ among studies. In the region of Lake Constance in Europe, Bohning-Gaese (1997) found that diversity of habitat types explained $30.7 \%$ of the variation in bird species richness, while climate factors explained less than 3.3\%. Across South Africa, climate and productivity explained $52 \%$ and habitat variety and evenness explained $32 \%$ of the variation in bird species richness (van Rensburg et al. 2002). In the Buenos Aires Province, Argentina, the $R^{2}$ was 0.65 for climate variables and 0.65 for numbers of vegetation strata (Cueto and de Casenave 1999). One factor that likely contributes to these differences is the magnitude of the gradient of energy and habitat within

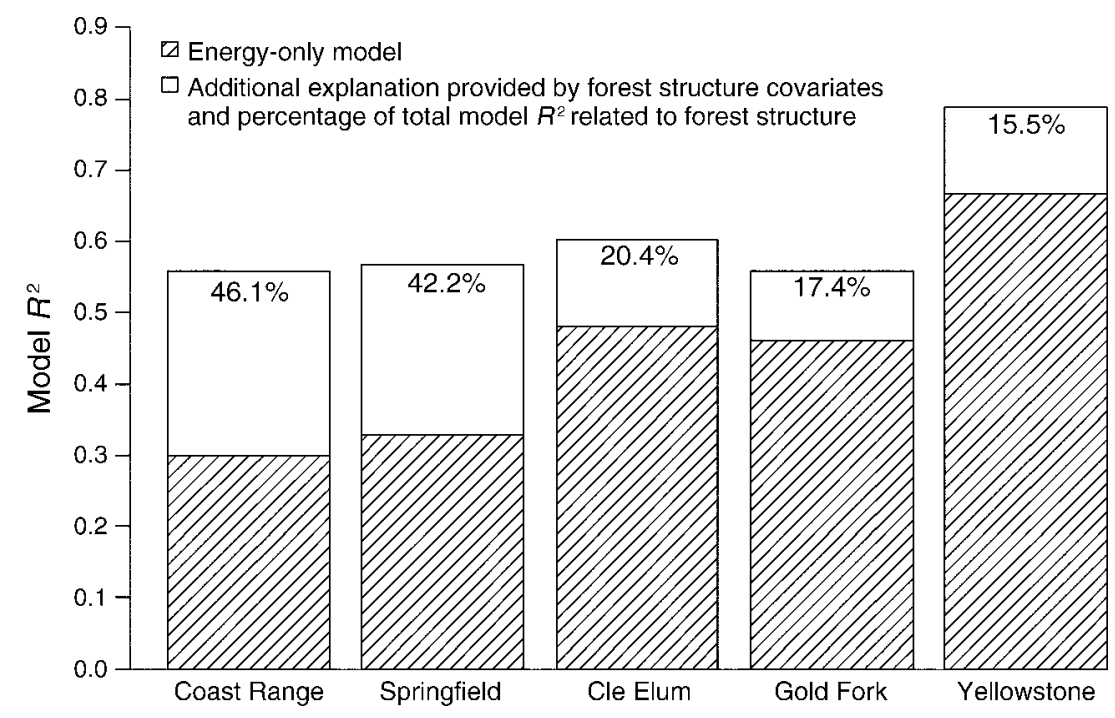

FIG. 4. Model $R^{2}$ and percentage of the total model $R^{2}$ resulting from the addition of five predictors of forest structure to a fivepredictor energy model at each landscape. 
TABLE 10. Predictors from 10 best predictor structure-first models by landscape.

\begin{tabular}{|c|c|c|c|c|c|c|}
\hline Landscape & Model & & & Predictors & & \\
\hline Coast Range & $\begin{array}{l}\text { structure } \\
\text { energy }\end{array}$ & $\begin{array}{l}\text { stdev.canopy } \\
\text { radavgas }\end{array}$ & $\begin{array}{l}\text { stdev.canopy }^{2} \\
\text { ndvi145 }\end{array}$ & $\begin{array}{l}\text { per.dec } \\
\text { ndvi1 } 45^{2}\end{array}$ & $\begin{array}{l}\text { per.dec } \\
\text { ndvi } 145^{3}\end{array}$ & $\begin{array}{l}\text { per.dec }{ }^{3} \\
\text { grosuman }\end{array}$ \\
\hline Springfield & structure & trdiv & $\operatorname{trdiv}^{2}$ & $\operatorname{trdiv}^{3}$ & qmd & stdev.canopy \\
\hline Cle Elum & $\begin{array}{l}\text { energy } \\
\text { structure } \\
\text { energy }\end{array}$ & $\begin{array}{l}\text { ndvi145 } \\
\text { num.mtree } \\
\text { radavgas }\end{array}$ & $\begin{array}{l}\text { nppmodis } \\
\text { num.mtree } \\
\text { preavgan }\end{array}$ & $\begin{array}{l}\text { vpdavgjja } \\
\text { stdev.trdiv } \\
\text { preavgan }^{2}\end{array}$ & $\begin{array}{l}\text { gsi05 } \\
\text { stdev.trdiv } \\
\text { temavgmi }\end{array}$ & $\begin{array}{l}\text { preavgas } \\
\text { st.complex } \\
\text { tempavgmi }^{2}\end{array}$ \\
\hline Gold Fork & $\begin{array}{l}\text { structure } \\
\text { energy }\end{array}$ & $\begin{array}{l}\text { num.sap } \\
\text { tempavgmj }\end{array}$ & $\begin{array}{l}\text { lsnag } \\
\text { tempavgmj }\end{array}$ & $\begin{array}{l}\text { canopy } \\
\text { ndviavg }\end{array}$ & $\begin{array}{l}\text { canopy }^{2} \\
\text { frosuman }\end{array}$ & $\begin{array}{l}\text { shade.sap } \\
\text { frosuman }^{2}\end{array}$ \\
\hline Yellowstone & $\begin{array}{l}\text { structure } \\
\text { energy }\end{array}$ & $\begin{array}{l}\text { canopy } \\
\text { gsi05 }\end{array}$ & $\begin{array}{l}\text { canopy } \\
\text { tempavgan }\end{array}$ & $\begin{array}{l}\text { qmd } \\
\text { ndviavg }\end{array}$ & $\begin{array}{l}\text { stdev.trdiv } \\
\text { frosuman }\end{array}$ & $\begin{array}{l}\text { snpp } \\
\text { ndviavgan }\end{array}$ \\
\hline
\end{tabular}

Note: See Appendix for all predictor definitions.

these study areas. Energy varied little relative to habitat diversity in the Lake Constance area where energy was a weak predictor. Strong climate and productivity gradients existed across South Africa, where energy was a strong predictor. In the South Africa study site, NPP ranged from near 0 to $1100 \mathrm{~g} \mathrm{C} \cdot \mathrm{cm}^{-2} \cdot \mathrm{yr}^{-1}$, a range similar to that of the northwestern United States and North America as a whole. A second factor affecting the relative influences of habitat and energy on diversity is the resolution of the analyses. The three studies above and Fraser (1998), Rahbek and Graves (2001), and Hurlbert and Haskell (2003) all found that habitat variety was an increasingly strong predictor when analyses were done in increasingly large sample units. Van Rensburg et al. (2002) suggested that this is due to the increase in the range of heterogeneity in habitat diversity at coarser resolutions. Our results suggest that forest structure and available energy drive species diversity with varying strengths throughout the northwestern United States, and that management will be most effective when accounting for the strength of energy limitations.
There are many other potential drivers of diversity that we could not consider in this analysis (e.g., competition, home-range size, food availability, or larger scale landscape-level features). We did not expect to explain all of the variation in species richness using only forest structure and energy covariates. In some landscapes, forest structure data collection methods prevented the forest structure-species richness relationship from being directly compared with other landscapes. Bird species richness has proven to be a valuable indicator of overall biodiversity (Furness and Greenwood 1993). However, forest ecosystem health may not always be positively related to species richness or biodiversity (Simberloff 1999). Therefore, management guidelines derived from analyses using only species richness (total land bird or species of concern) may miss the importance of specialist species and habitat types (Kareiva and Marvier 2003).

\section{Management implications}

Biodiversity management will be most effective if it is tailored to the local setting especially in energy-limited

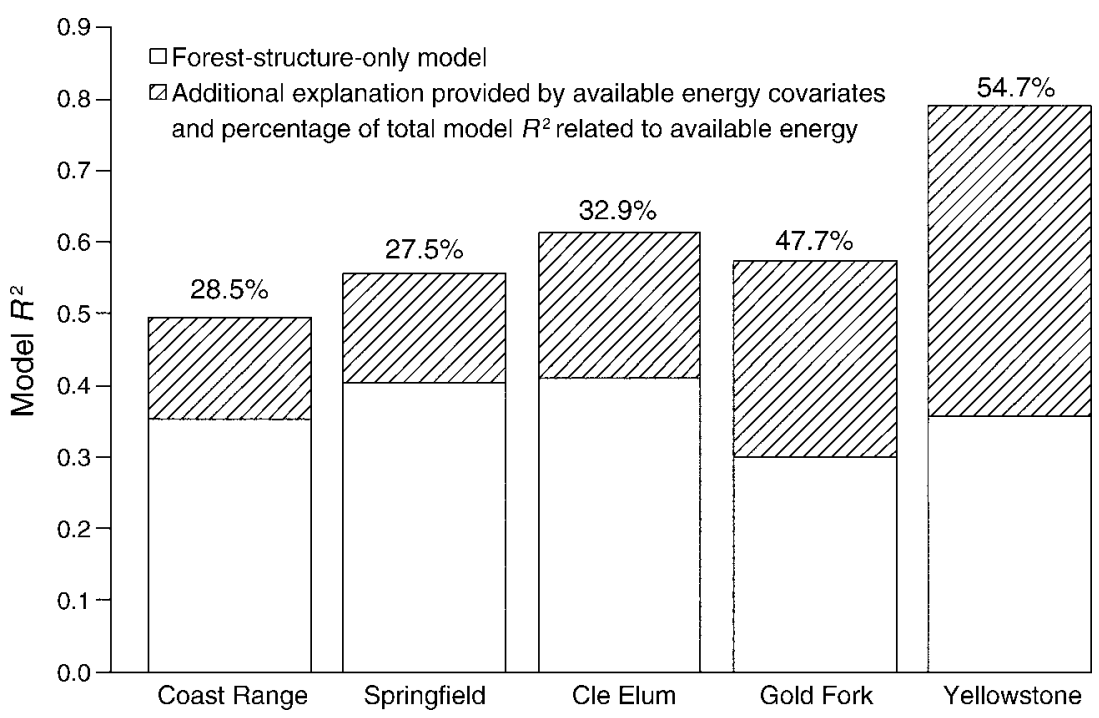

FIG. 5. Model $R^{2}$ and percentage of the total model $R^{2}$ resulting from the addition of five predictors of available energy to a five-predictor forest structure model at each landscape. 
TABle 11. Direction (Dir.) and significance (Sig.) of relationships between covariates representing structural complexity and species richness for the five landscapes.

\begin{tabular}{|c|c|c|c|c|c|c|c|c|c|c|}
\hline \multirow{2}{*}{$\begin{array}{c}\text { Structural } \\
\text { complexity measure }\end{array}$} & \multicolumn{2}{|c|}{ Coast Range } & \multicolumn{2}{|c|}{ Springfield } & \multicolumn{2}{|c|}{ Cle Elum } & \multicolumn{2}{|c|}{ Gold Fork } & \multicolumn{2}{|c|}{ Yellowstone } \\
\hline & Sig. & Dir. & Sig. & Dir. & Sig. & Dir. & Sig. & Dir. & Sig. & Dir. \\
\hline Tree size diversity & ns & & $* *$ & Cubic $(-)$ & ns & & ns & & ns & \\
\hline SCI & $\begin{array}{l}* \\
*\end{array}$ & + & $\begin{array}{c}* * \\
*\end{array}$ & - & $* * *$ & + & $\mathrm{ns}_{*}$ & & $* *$ & + \\
\hline Shrub cover & $*$ & - & $*$ & + & ns & & $*$ & Quadratic & ns & \\
\hline
\end{tabular}

Notes: See Table 3 for units of measure. SCI is a structural complexity index of horizontal vertical variation in tree size and density, computed as (tree size diversity) $\times(\mathrm{SD}$ of tree density between 20 subplots $) \times 100$. Direction is either positive $(+)$ or negative (-). Significance is: ns, not significant; ${ }^{*} P<0.05 ; * * P<0.01 ; * * P<0.001$.

landscapes. Hansen et al. (2003) found that in lowenergy landscapes in the northwestern United States, biodiversity was concentrated in small localized hotspots with high energy. These hotspots not only contain many species, and high population densities, they are also sometimes population source areas that maintain viable populations across the larger landscape (Hansen and Rotella 2002). In low-energy locations, it is important to identify and judiciously manage these hotspots. Forest managers in the past have often harvested intensively in such hotspots, sometimes leading to a change in dominant cover type, a loss of structural complexity, and reduced duration of later seral stages (Hansen et al. 2003). Given that disturbance is a natural component of low-energy locations, it is likely that some level of disturbance will best maintain diversity in these hotspots, but the type, rate, and intensity needs be carefully matched to local conditions.
Across the remainder of low-energy regions, management will best maintain biodiversity if it takes into account the longer rotation periods required to maintain the long term ecological productivity of the site. D. B. McWethy, J. P. Verschuyl, and A. J. Hansen (unpublished manuscript) found that disturbance reduced diversity in low-productivity landscapes possibly because disturbance reduces resources and recovery rates of organisms. Harvest rates and intensities may be based on the goals of promoting rapid recolonization of disturbed landscapes and maintaining populations of species dependent on late-seral forests. In addition, when harvesting smaller forest tracts in energy-limited regions comprised primarily of lodgepole pine, management that promotes increased shrub density and size will likely benefit local scale biodiversity. However, when managing the entire biophysical gradient that exists at Yellowstone, management attentions would be better

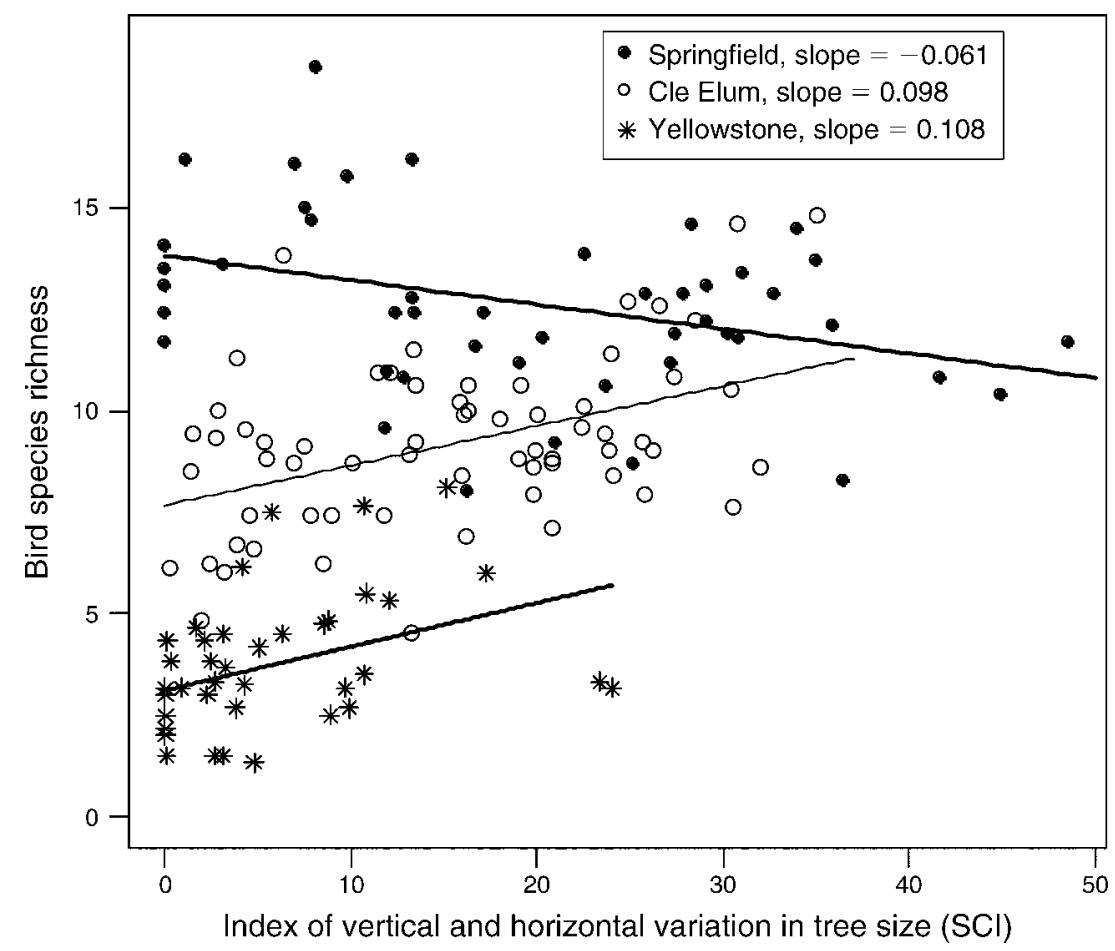

FIG. 6. Comparison of slopes between bird species richness and an index of vertical and horizontal variation in tree size (SCI) at the Springfield, Cle Elum, and Yellowstone landscapes. 
focused in comparatively high-energy foothill and river bottom locations.

In energy-rich environments, growing conditions are often good over most of the landscape. Thus, most places across the landscape have high potential to support biodiversity. Here, diversity may be limited by competitive dominance of a few plant species leading to specialized bird communities. In such high-energy locations, disturbance can act to break competitive dominance of plants and free resources, dividing homogeneous forests into a variety of habitat types that support a greater diversity of bird species (Huston 1999, 2004; D. B. McWethy, J. P. Verschuyl, and A. J. Hansen, unpublished manuscript). Many species in energy-rich environments specialize in forest interior, edge, or early-seral conditions. Hence, creation of the full suite of seral stages and attention to patch size and edge relationships is especially important. Therefore, a shifting mosaic of patches of different seral stages across the landscape may increase diversity at the landscape scale (D. B. McWethy, J. P. Verschuyl, and A. J. Hansen, unpublished manuscript).

The unimodal relationship between diversity and structural complexity in early seral stages at the Springfield landscape has revealed potentially critical habitat that reaches a diversity peak just before canopy closure occurs. At the remaining four landscapes where higher levels of species richness correspond with older seral stages and higher levels of structural complexity, the older forests may be of greater value to species diversity.

\section{ACKNOWLEDGMENTS}

We thank the National Council for Air and Stream Improvement (NCASI) and the National Fish and Wildlife Foundation for their support of this research. We are grateful for the coordination and cooperation of industry land owners and biologists. We also thank data contributors Kevin McGarigal and William McComb, as well as the crews that worked hard to collect the field data.

\section{Literature Cited}

Bailey, S. A., M. C. Horner-Devine, G. Luck, L. A. Moore, K. M. Carney, S. Anderson, C. Betrus, and E. Fleishman. 2004. Primary productivity and species richness: relationships among functional guilds, residency groups and vagility classes at multiple spatial scales. Ecography 27:207-217.

Bohning-Gaese, K. 1997. Determinants of avian species richness at different spatial scales. Journal of Biogeography 24:49-60.

Bonn, A., D. Storch, and K. J. Gaston. 2004. Structure of the species-energy relationship. Proceedings of the Royal Society B 271:1685-1691.

Brown, E. R., technical editor. 1985. Management of wildlife and fish habitats in forests of western Oregon and Washington. R6-F\&WL-192. U.S. Department of Agriculture, Forest Service, Pacific Northwest Research Station, Portland, Oregon, USA.

Burnham, K. P., and D. R. Anderson. 1998. Model selection and inference: a practical information-theoretic approach. Springer, New York, New York, USA.

Carey, A. B. 1998. Ecological foundations of biodiversity: lessons from natural and managed forests of the Pacific Northwest. Northwest Science 72:127-133.
Carey, A. B., J. Kershner, B. Biswell, and L. D. de Toledo. 1999. Ecological scale and forest development: squirrels, dietary fungi, and vascular plants in managed and unmanaged forests. Wildlife Monographs 142:1-71.

Chase, J. M., and M. A. Leibold. 2002. Spatial scale dictates the productivity-biodiversity relationship. Nature 416:427-430.

Cueto, V. R., and J. de Casenave. 1999. Determinants of bird species richness: role of climate and vegetation structure at a regional scale. Journal of Biogeography 26:487-492.

Currie, D. J. 1991. Energy and large-scale patterns of animaland plant-species richness. American Naturalist 137:27-49.

Erdelen, M. 1984. Bird communities and vegetation structure: I. Correlations and comparisons of simple and diversity indices. Oecologia 61:277-284.

Franklin, J. F., and T. A. Spies. 1991. Composition, function and structure of old-growth Douglas-Fir forests. PNW-GTR 285. U.S. Department of Agriculture, Forest Service, Pacific Northwest Research Station, Portland, Oregon, USA.

Fraser, R. H. 1998. Vertebrate species richness at the mesoscale: relative roles of energy and heterogeneity. Global Ecology and Biogeography 7:215-220.

Furness, R. W., and J. J. D. Greenwood. 1993. Birds as monitors of environmental change. Chapman and Hall, New York, New York, USA.

Halpern, C. B., and T. A. Spies. 1995. Plant species diversity in natural and managed forests of the Pacific Northwest. Ecological Applications 5:913-934.

Hansen, A. J., and J. J. Rotella. 1999. Abiotic factors. Pages 161-209 in M. L. Hunter, editor. Maintaining biodiversity in forest ecosystems. Cambridge University Press, Cambridge, UK.

Hansen, A. J., and J. J. Rotella. 2002. Biophysical factors, land use, and species viability in and around nature reserves. Conservation Biology 16:1-12.

Hansen, A. J., J. J. Rotella, M. P. V. Kraska, and D. Brown. 2000. Spatial patterns of primary productivity in the Greater Yellowstone ecosystem. Landscape Ecology 15:505-522.

Hansen, A. J., T. A. Spies, F. J. Swanson, and J. L. Ohmann. 1991. Conserving biodiversity in managed forests: lessons from natural forests. BioScience 41:382-392.

Hansen, A., R. Waring, L. Phillips, J. Swenson, and C. Loehle. 2003. Using biophysical factors to predict regional biodiversity potential in the Pacific and Inland Northwest. Final Report Submitted to National Council for Air and Stream Improvement (NCASI), Research Triangle Park, North Carolina, USA.

Harris, L. D. 1984. The fragmented forest: island biogeography theory and the preservation of biotic diversity. University of Chicago Press, Chicago, Illinois, USA.

Hawkins, B. A., R. Field, H. V. Cornell, D. J. Currie, J. Guegan, D. M. Kaurman, J. T. Kerr, G. G. Mittelbach, T. Oberdorff, E. M. O’Brian, E. E. Porter, and J. R. G. Turner. 2003. Energy, water and broad-scale geographic patterns of species richness. Ecology 84:3105-3117.

Heinsch, F. A., et al. 2003. User's guide: GPP and NPP (MOD17A2/A3) products, NASA MODIS land algorithm. University of Montana, Missoula, Montana, USA.

Heinsch, F. A., et al. 2006. Evaluation of remote sensing based terrestrial productivity from MODIS using regional tower eddy flux network observations. IEEE Transactions on Geoscience and Remote Sensing 44:1908-1925.

Hunter, M. L., Jr. 1999. Maintaining biodiversity in forest ecosystems. Cambridge University Press, Cambridge, UK.

Hurlbert, A. H. 2004. Species-energy relationships and habitat complexity in bird communities. Ecology Letters 7:714-720.

Hurlbert, A. H., and J. P. Haskell. 2003. The effect of energy and seasonality on avian species richness and community composition. American Naturalist 161:83-97.

Huston, M. A. 1994. Biological diversity: the coexistence of species on changing landscapes. Cambridge University Press, Cambridge, UK. 
Huston, M. A. 1999. Forest productivity and diversity: using ecological theory and landscape models to guide sustainable forest management. Pages 329-341 in C. Agurire-Bravo and C. R. Franco, compilers. North American science symposium: toward a unified framework for inventorying and monitoring forest ecosystem resources. USDA Forest Service, Washington, D.C., USA.

Huston, M. A. 2004. Management strategies for plant invasions: manipulations productivity, disturbance, and competition. Diversity and Distributions 10:167-178.

Irwin, L. L. 1999. Abiotic influences on bird-habitat relationships. Pages 209-218 in J. M. Marzluff and R. Salabanks, editors. Avian conservation: research and management. Island Press, Washington, D.C., USA.

Ishii, H. T., S. Tanabe, and T. Hiura. 2004. Exploring the relationships among canopy structure, stand productivity, and biodiversity of temperature forest ecosystems. Forest Science 50:342-355.

Kareiva, P., and M. Marvier. 2003. Conserving biodiversity coldspots. American Scientist 91:344-351.

Kohm, K. A., and J. F. Franklin, editors. 1997. Creating a forestry for the 21 st century: the science of ecosystem management. Island Press, Washington, D.C., USA.

Loehle, C., J. G. MacCracken, D. Runde, and L. Hicks. 2002. Forest management at landscape scales: solving the problems. Journal of Forestry 100:25-33.

MacArthur, R. H., and J. W. MacArthur. 1961. On bird species diversity. Ecology 42:594-598.

Magurran, A. E. 1988. Ecological diversity and its measurement. Princeton University Press, Princeton, New Jersey, USA.

McCann, K. S. 2000. The diversity-stability debate. Nature 405:228-233.

McElhinny, C., P. Gibbons, and C. Brack. 2005. Forest and woodland stand structural complexity: its definition and measurement. Forest Ecology and Management 218:1-24.

McGarigal, K., and W. C. McComb. 1995. Relationships between landscape structure and breeding birds in the Oregon Coast Range. Ecological Monographs 65:235-260.

Mittelbach, G. G., C. F. Steiner, S. M. Scheiner, K. L. Gross, H. L. Reynolds, R. B. Waide, M. R. Willig, S. I. Dodson, and L. Gough. 2001. What is the observed relationship between species richness and productivity? Ecology 82:2381-2396.

Monkkonen, M., J. T. Forsman, and F. Bokima. 2006. Energy availability, abundance, energy-use and species richness in forest bird communities: a test of the species energy theory. Global Ecology and Biogeography 15:290-302.

Noss, R. F. 1983. A regional landscape approach to maintain diversity. BioScience 33:700-706.

O'Connell, T. J., L. E. Jackson, and R. P. Brooks. 2000. Bird guilds as indicators of ecological condition in the central Appalachians. Ecological Applications 10:1706-1721.

Oliver, C., R. Greggs, L. Hicks, and S. Boyd. 1995. Forest stand structural classification system developed for the Plum Creek Cascades Habitat Conservation Plan. Technical Report No. 10. Plum Creek Timber Company, L.P., Seattle, Washington, USA.

Oliver, C. D., and B. C. Larson. 1990. Forest stand dynamics. McGraw Hill, New York, New York, USA.

Rahbek, C., and G. R. Graves. 2001. Multiscale assessment of patterns of avian species richness. Proceedings of the National Academy of Science (USA) 98:4534-4539.

Ralph, C. J., S. Droege, and J. R. Sauer. 1995. Managing and monitoring birds using point counts: standards and applications. General Technical Report PSW-GTR-149. U.S.
Department of Agriculture, Forest Service, Pacific Northwest Region, Portland, Oregon, USA.

Rapp, V. 2004. Ecosystems and people: managing forests for mutual gains. Science update 8. U.S. Department of Agriculture, Forest Service, Pacific Northwest Research Station, Portland, Oregon, USA.

Running, S. W., R. R. Nemai, F. A. Heinsch, M. Zhao, and M. Reeves. 2004. A continuous satellite-derived measure of global terrestrial primary production. BioScience 54:547-560.

Sallabanks, R., and E. B. Arnett. 2005. Accommodating birds in managed forests of North America: a review of birdforestry relationships. PSW-GTR-191. U.S. Department of Agriculture, Forest Service, Pacific Northwest Region, Portland, Oregon, USA.

Sallabanks, R., J. B. Haufler, and C. A. Mehl. 2006. Influence of forest vegetation structure on avian community composition in west-central Idaho. Wildlife Society Bulletin 34: 1079-1093.

Sallabanks, R., R. A. Riggs, and L. E. Cobb. 2002. Bird use of forest structural classes in grand fir forests of the Blue Mountains, Oregon. Forest Science 48:311-321.

Shannon, C., and W. Weaver. 1949. The mathematical theory of communication. University of Illinois Press, Urbana, Illinois, USA.

Simberloff, D. 1999. The role of science in the preservation of forest biodiversity. Forest Ecology and Management 115: 101-111.

Spies, T. A. 1998. Forest structure: a key to the ecosystem. Northwest Science 72:35-39.

Spies, T. A., and J. F. Franklin. 1991. The structure of natural young, mature, and old-growth Douglas-Fir forests in Oregon and Washington. PNW-GTR 285. U.S. Department of Agriculture, Forest Service, Pacific Northwest Research Station, Portland, Oregon, USA.

Thomas, J. W., editor. 1979. Wildlife habitats in managed forests: the Blue Mountains of Oregon and Washington. Agriculture Handbook \#533. USDA Forest Service, Washington, D.C., USA.

Thomas, L., S. T. Buckland, K. P. Burnham, D. R. Anderson, J. R. Laake, D. L. Borchers, and S. Strindberg. 2002. Distance sampling. Pages 544-552 in A. H. El-Shaarawi and W. W. Piegorsch, editors. Encyclopedia of environmetrics. John Wiley and Sons, Chichester, UK.

Thornton, P. E., S. W. Running, and M. A. White. 1997. Generating surfaces of daily meteorological variables over large regions of complex terrain. Journal of Hydrology 190: 214-251.

Tilman, D., J. Knops, D. Wedin, P. Reich, M. Ritchie, and E. Siemann. 1997. The influence of functional diversity and composition on ecosystem processes. Science 277:1300-1302.

van Rensburg, B. J., S. L. Chown, and K. J. Gaston. 2002. Species richness, environmental correlates and spatial scale: a test using South African birds. American Naturalist 159:566577.

Waide, R. B., M. R. Willig, S. F. Steiner, G. Mittelbach, L. Gough, S. I. Dodson, G. P. Juday, and R. Parmenter. 1999. The relationship between productivity and species richness. Annual Review of Ecology and Systematics 30:257-300.

Wilson, D. S., and K. J. Puettmann. 2007. Density management and biodiversity in young Douglas-fir forests: challenges of managing across scales. Forest Ecology and Management 246:123-134.

Zenner, E. K., and D. E. Hibbs. 2000. A new method for modeling the heterogeneity of forest structure. Forest Ecology and Management 129:75-87. 